in vivo $35: 2675-2685(2021)$

doi:10.21873/invivo.12551

\title{
Cytotoxic Activity of Isoniazid Derivative in Human Breast Cancer Cells
}

\author{
MUTTIAH BARATHAN ${ }^{1}$, AHMAD KHUSAIRY ZULPA ${ }^{1}$, KUMUTHA MALAR VELLASAMY ${ }^{1}$, \\ VANITHA MARIAPPAN ${ }^{2}$, NAVEEN KUMAR HAWALA SHIVASHEKAREGOWDA ${ }^{3}$, \\ ZARIDATUL AINI IBRAHIM ${ }^{4}$ and JAMUNA VADIVELU ${ }^{1}$ \\ ${ }^{1}$ Department of Medical Microbiology, Faculty of Medicine, Universiti Malaya, Kuala Lumpur, Malaysia; \\ ${ }^{2}$ Center of Toxicology and Health Risk Studies (CORE), Faculty of Health Sciences, \\ Universiti Kebangsaan Malaysia, Kuala Lumpur, Malaysia; \\ ${ }^{3}$ School of Pharmacy, Taylor's University, Lakeside Campus, Selangor, Malaysia; \\ ${ }^{4}$ Department of Pharmacology, Faculty of Medicine, Universiti Malaya, Kuala Lumpur, Malaysia
}

\begin{abstract}
Background/Aim: Isoniazid is an antibiotic used for the treatment of tuberculosis. Previously, we found that the isoniazid derivative (E)-N'-(2,3,4-trihydroxybenzylidene) isonicotinohydrazide (ITHB4) could be developed as novel antimycobacterial agent by lead optimization. We further explored the ability of this compound compared to zerumbone in inhibiting the growth of MCF-7 breast cancer cells. Materials and Methods: Cytotoxicity was measured by the MTT assay and further confirmed via apoptosis, ROS, cell cycle, DNA fragmentation and cytokine assays. Results: ITHB4 demonstrated a lower $I C_{50}$ compared to zerumbone in inhibiting the proliferation of MCF-7 cells. ITHB4 showed no toxicity against normal breast and human immune cells. Apoptosis assay revealed that ITHB4, at a concentration equal to the $I C_{50}$, induces apoptosis of MCF-7 cells and cell cycle arrest at the sub-G1 and $G_{2} / M$ phases. ITHB 4 triggered accumulation of intracellular ROS and nuclear DNA fragmentation. Secretion of pro-inflammatory cytokines induced inflammation and potentially immunogenic cell death. Conclusion: ITHB4 has almost similar chemotherapeutic properties as zerumbone in inhibiting MCF-7 growth, and hence provide the basis for further experiments in animal models.
\end{abstract}

This article is freely accessible online.

Correspondence to: Jamuna Vadivelu, Department of Medical Microbiology, Faculty of Medicine, Universiti Malaya, Kuala Lumpur 50603, Malaysia. Tel: +603 79676662, e-mail: jamuna@um.edu.my

Key Words: Apoptosis, synthetic compound, reactive oxygen species, cytokine, zerumbone, isoniazid, breast cancer cells.
Breast cancer is the most frequent cancer among women, impacting 2.1 million women each year (1). In 2020, the GLOBOCAN report indicated that $24.5 \%$ of cancer cases among females belong to breast cancer, and estimated that 684,996 women died from breast cancer (1). While breast cancer rates are higher among women in more developed regions, rates are predicted to increase in nearly every region globally. Early diagnosis and aggressive treatment/prevention strategies such as surgery in combination with chemotherapy and radiotherapy are the current clinical approaches to combat this disease (2). However, tumor recurrence remains a major problem in the treatment of breast cancer. Moreover, the broad-spectrum actions of chemotherapy and radiotherapy agents that are not selective in killing cancer cells cause many unwanted side effects in patients (3). Hence, these called for urgent measures and innovations in anti-cancer therapy to effectively treat this disease.

In recent years, there is an emerging research on developing novel synthetic lead compounds from various plant and animal species as well as non-marine and marine microbes, as promising treatment modalities against cancer (4). These synthetic anti-cancer compounds are molecularly replicated to mimic the naturally-occurring compounds, with better properties, including more sustainable, cost effective, and with higher selectivity against cancer than normal cells (5). Some of the synthetic anticancer agents including sorafenib and methotrexate, act as tyrosine kinase inhibitors and antimetabolites, respectively, which are used in clinical practice (6). There is also new evidence indicating that antibiotics are effective not only in treating bacterial infections, but also in eradicating cancer stem cells without harming normal cells $(7,8)$. For instance, doxycycline is an antibiotic used to treat bacterial infections like urinary tract infections and acne, and current findings have suggested that it also inhibits the growth of cancer stem cells (7). With these 
<smiles>O=C(N/N=C/c1ccc(O)c(O)c1O)c1ccncc1</smiles>

Figure 1. The structures of $(E)-N^{\prime}-(2,3,4$-trihydroxybenzylidene) isonicotinohydrazide (ITHB4).

in vitro proof-of-concept data, and further research, many new anti-cancer treatments will be developed in the near future. This has led us to investigate the potential anticancer properties of one of our synthesized isoniazid derivatives. We have evaluated the antimycobacterial activities of several isoniazid analogues in our previous research (9). We have identified that one of the isoniazid derivatives, (E)-N'-(2,3,4trihydroxybenzylidene)isonicotinohydrazide (ITHB4), could be developed as a novel antimycobacterial agent through lead optimization. The same compound was also tested on the human colon cancer cell line HCT 116, showing promising cytotoxic effects (10). In this study, we aimed to examine the potential anticancer properties of ITHB4 against breast cancer cells and elucidate the possible molecular mechanisms by which this may occur in MCF-7 breast carcinoma cells. We compared the activity of ITHB4 with the natural phytochemical zerumbone isolated from the subtropical Zingiberaceae family of flowering plants. Zerumbone has different biomedical properties such as antioxidant, antiinflammatory, and anti-proliferative (11). Similar to ITHB4, zerumbone has also been found to inhibit colony growth of Mycobacterium tuberculosis on Lowenstein Jensen medium (12). Additionally, zerumbone is known to exert selective toxicity toward various cancer cell lines including breast cancer (13). Hence, we investigated whether ITHB4 may also serve as an anticancer agent similar to zerumbone.

\section{Materials and Methods}

Synthesis and purification of the test compounds. ITHB4 was prepared according to the procedure reported in our previous work (14). The structures of the isoniazid analogues and the reaction pathway are given in Figures 1 and 2. The lead compound was prepared by the reaction of 2,3,4-trihydroxybenzaldehyde (1.0 eq) with isoniazid $(1.0 \mathrm{eq})$ in ethanol/water. After stirring for 1-3 h at room temperature, the resulting mixture was concentrated under reduced pressure. The residue, purified by washing with cold ethanol and ethyl ether, afforded the pure derivative. Brown-coloured single crystals suitable for X-ray analysis were obtained by recrystallization with ethanol. The chemical structure of the lead compound was characterized by using various spectroscopic methods and the final structure was confirmed by x-ray crystallography (12).

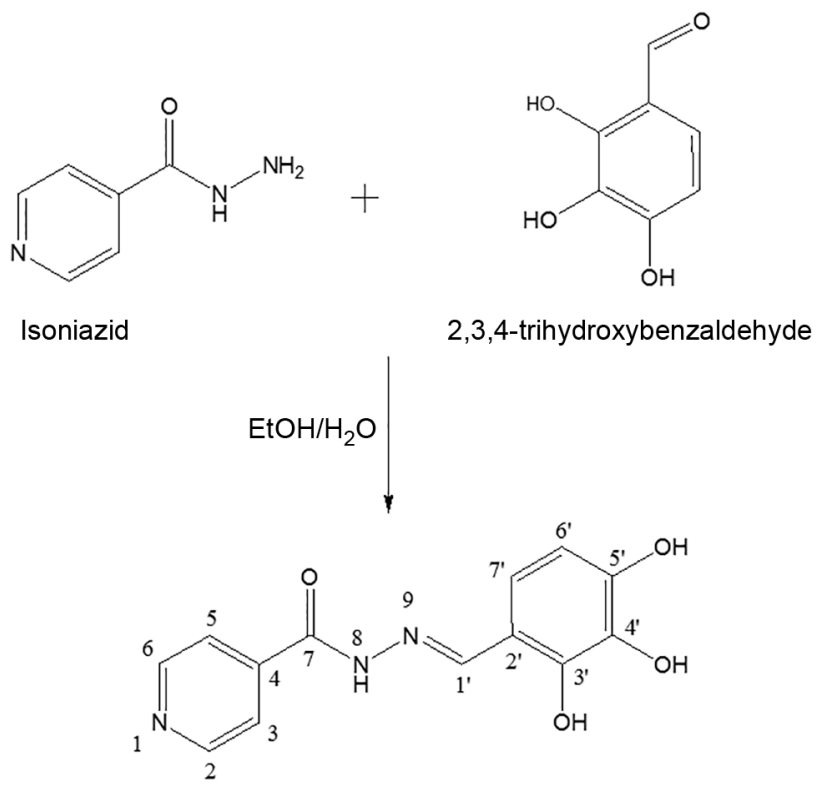

(E)- $N^{\prime}$-(2,3,4-trihydroxybenzylidehyde) isonicotinohydrazide

Figure 2. Synthetic route used for the preparation of (E)-N'-(2, 3, 4trihydroxybenzylidene)isonicotinohydrazide (ITHB4).

The lead compound comprises of ITHB4 molecule and two water molecules of crystallization (Figure 1). The Schiff base molecule exists in an $\mathrm{E}$ configuration with respect to the acyclic $\mathrm{C} 7=\mathrm{N} 3$ bond $[\mathrm{C} 7=\mathrm{N} 3=1.2921$ (10) $\AA$; torsion angle N2 - N3-C7-C8=178.85 $(7)^{\circ}$ ]. An intramolecular $\mathrm{O} 2-\mathrm{H} 1 \mathrm{O} 2 \cdots \mathrm{N} 3$ hydrogen bond generates a six-membered ring, producing an $\mathrm{S}(6)$ ring motif. The pyridine ring with atom sequence $\mathrm{C} 1 / \mathrm{C} 2 / \mathrm{N} 1 / \mathrm{C} 3 / \mathrm{C} 4 / \mathrm{C} 5$ is essentially planar, with a maximum deviation of 0.0119 (8) $\AA$ at atom C5. There is a slight inclination between the pyridine and benzene rings, as indicated by the dihedral angle formed of 7.30 (4). All bond lengths and angles are consistent with those observed in closely related isoniazid structures.

In the crystal packing, water molecules play an important role in forming the hydrogen-bonded structure. Neighboring molecules are linked into two-dimensional arrays parallel to the (101) plane by intermolecular $\mathrm{O} 3-\mathrm{H} 1 \mathrm{O} 3 \cdots \mathrm{N} 1, \quad \mathrm{O} 4-\mathrm{H} 1 \mathrm{O} 4 \cdots \mathrm{O} 1 \mathrm{~W}, \quad \mathrm{~N} 2-$ $\mathrm{H} 1 \mathrm{~N} 2 \cdots \mathrm{O} 2 \mathrm{~W}, \mathrm{O} 1 \mathrm{~W}-\mathrm{H} 1 \mathrm{~W} 1 \cdots \mathrm{O} 1, \mathrm{O} 2 \mathrm{~W}-\mathrm{H} 2 \mathrm{~W} 2 \cdots \mathrm{O} 4$ and $\mathrm{C} 7-$ $\mathrm{H} 7 \mathrm{~A} \cdots \mathrm{O} 2 \mathrm{~W}$ hydrogen bonds. These arrays are further interconnected by intermolecular $\mathrm{O} 1 \mathrm{~W}-\mathrm{H} 2 \mathrm{~W} 1 \cdots \mathrm{O} 2 \mathrm{~W}, \mathrm{O} 2 \mathrm{~W}-$ $\mathrm{H} 1 \mathrm{~W} 2 \cdots \mathrm{O} 2$ and $\mathrm{C} 4-\mathrm{H} 4 \mathrm{~A} \cdots \mathrm{O} 1$ hydrogen bonds into a threedimensional extended structure. Weak intermolecular $\pi-\pi$ aromatic stacking interactions involving the pyridine and benzene rings $[\mathrm{Cg} 1 \cdots \mathrm{Cg} 2=3.5627$ (5) $\AA$, symmetry code: $-\mathrm{x}+2,-\mathrm{y}+1,-\mathrm{z}+2]$ are present stabilizing the crystal structure.

ITHB4 spectral data: Pale brown solid; UV $(\lambda \max ): 331 \mathrm{~nm} . \mathrm{IR}$ (cm-1; KBr) $3383(\mathrm{OH}), 3256(\mathrm{NH}), 1659(\mathrm{C}=\mathrm{O}), 1618(\mathrm{C}=\mathrm{N}) .1 \mathrm{H}$ NMR (DMSO-d6, $400 \mathrm{MHz}$ ) d: 12.18 (s, 1H, -CONH), 11.29 (s, $1 \mathrm{H},-\mathrm{OH}), 9.58(\mathrm{~s}, 1 \mathrm{H},-\mathrm{OH}), 8.80-8.78[\mathrm{dd}, 2 \mathrm{H}, \mathrm{J}=5.92 \mathrm{~Hz}, 2.2$ $\mathrm{Hz},(\mathrm{Pr}-\mathrm{a}-\mathrm{CH})], 8.56$ (s, 1H, OH), 8.49 (s, 1H, N=CH), 7.84-7.82 [dd, $2 \mathrm{H}, \mathrm{J}=5.88 \mathrm{~Hz}, 2.2 \mathrm{~Hz},(\mathrm{Pr}-\alpha-\mathrm{CH})], 6.85-6.82$ [d, $1 \mathrm{H}, \mathrm{J}=11.4$ $\mathrm{Hz}(\mathrm{Ar}-\mathrm{H})], 6.42-6.39$ [d, 1H, J=11.28 Hz, (Ar-H)]. 13C NMR

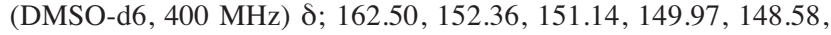


$141.05,133.70,122.23,111.81,108.76$. MS-ESI m/z (\%)-[M+Na]+ 296.10 (100). Anal. Calcd for C13H11 N3 O4 (273.07) C, 57.14; H, 4.06; N, 15.38; found C.57.11; H, 4.09; N, 15.36.

Chemicals and reagents. For synthesis of ITHB4, 2,3,4-trihydroxy benzaldehyde and isoniazid were obtained from Millipore SigmaAldrich (St. Louis, MO, USA). HPLC grade solvents were used for the reaction. Reagents and all solvents were analytically pure and used without further purification. Pre-coated aluminium sheets silica gel 60 F254 (Merck, Darmstadt, Germany), TLC plates were used for monitoring the progress of the reaction, using dichloromethane/methanol as a mobile phase. All chemicals and solvents used were of the highest analytic grade available. Cell culture supplies and media, fetal bovine serum (FBS), sodium pyruvate, nonessential amino acids, penicillin/streptomycin and DMSO were obtained from Sigma Aldrich (Malaysia). Zerumbone (positive control) and 3-(4,5-dimethylthiazol-2yl)-2,5-diphenyltetrazolium bromide (MTT) used in this study were purchased from Sigma Aldrich (Malaysia).

Cell culture. Human estrogen-dependent breast carcinoma (MCF-7) cell line and non-tumorigenic epithelial cell line (MCF10A) were purchased from the American Type Culture Collection (Rockville, MD, USA). MCF10A cells were cultured in Dulbecco's Modified Eagle Medium (DMEM)/F12 Ham's mixture supplemented with $10 \%$ of FBS (Sigma), $10 \mathrm{ng} / \mathrm{ml}$ of epidermal growth factor (Sigma), $10 \mu \mathrm{g} / \mathrm{ml}$ of insulin (Sigma), $0.5 \mathrm{mg} / \mathrm{ml}$ of hydrocortisone (Sigma), $100 \mathrm{ng} / \mathrm{ml}$ of cholera toxin (Sigma), $100 \mathrm{units} / \mathrm{ml}$ of penicillin and $100 \mu \mathrm{g} / \mathrm{ml}$ of streptomycin. Meanwhile, MCF-7 cells were propagated in high glucose DMEM supplemented with $10 \%$ fetal bovine serum, $2 \mathrm{mM}$ L-glutamine, 100 units $/ \mathrm{ml}$ of penicillin and $100 \mu \mathrm{g} / \mathrm{ml}$ of streptomycin. All these cells were propagated in a $37^{\circ} \mathrm{C}$ humidified incubator with $5 \% \mathrm{CO}_{2}$.

Peripheral blood mononuclear cell (PBMC) isolation and maintenance. Isolation of PBMCs from buffy coats was carried out as previously described (15). Briefly, $10 \mathrm{ml}$ of whole blood was obtained per healthy individual in BD Vacutainer heparin lithium tubes (BD Biosciences, Franklin Lakes, NJ, USA), and PBMCs were isolated by density-gradient centrifugation over FicollPaqueTM (Amersham Pharmacia, Piscataway, NJ, USA). The cells were resuspended in a freezing medium (10\% DMSO in $90 \%$ fetal bovine serum (FBS) (Gibco, Carlsbad, CA, USA) and cryopreserved in liquid nitrogen until use. This part of the study was carried out following approval by the Medical Ethics Committee (MEC) of the University of Malaya Medical Center (ref.no. 938.42). Written consent was obtained from all the participants before study enrollment.

Primary cell culture. PBMCs were propagated in RPMI1640 medium supplemented with HEPES buffer $(25 \mathrm{mM})$, L-glutamine ( $2 \mathrm{mM})$, penicillin $(100 \mathrm{U} / \mathrm{ml})$, streptomycin $(100 \mathrm{lg} / \mathrm{ml})$, sodium pyruvate $(1 \mathrm{mM})$, gentamicin $(1 \mathrm{mg} / \mathrm{ml})$ (all procured from Life Technologies, Victoria, Australia), and 10\% of FBS (Gibco). IL-2 was added to the PBMC culture to increase proliferation of the cells. These cells were propagated in a $37^{\circ} \mathrm{C}$ humidified incubator with $5 \% \mathrm{CO}_{2}$ for $24 \mathrm{~h}$.

In vitro cytotoxicity assay of ITHB 4 in MCF-7 and MCF10A cells. The half maximal inhibitory concentration $\mathrm{IC}_{50}$ (i.e. the concentrations at which cell growth was reduced by half) of ITHB4 on MCF-7 cells was determined by using the MTT assay. The cells were plated in triplicates in a 96-well plate at a density of $2 \times 10^{5}$ cells $/ \mathrm{ml}$ in $100 \mu \mathrm{l}$ of culture medium. ITHB 4 was dissolved in DMSO at $1 \mathrm{mg} / \mathrm{ml}$, from which working solutions were prepared in a complete culture medium prior to treatments. These working solutions were prepared by serial dilution as such 200, 175, 150, $125,100,75,50$ and $25 \mu \mathrm{g} / \mathrm{ml}$. Untreated MCF-7 cells were used as a negative control in this experiment. The cells were incubated for 24 and $48 \mathrm{~h}$, respectively, after which their viability was assessed by adding $20 \mu \mathrm{l}$ of MTT, $5 \mathrm{mg} / \mathrm{ml}$, to the cells in a dark condition. The plates were then covered with aluminum foil and incubated for another $4 \mathrm{~h}$. Then, all the media were removed and $100 \mu \mathrm{l}$ of DMSO was added to the cells to solubilize the formazan crystals. Subsequently, the absorbance was read at a wavelength of $570 \mathrm{~nm}$ using a microplate reader. The cell growth inhibition abilities of ITHB4 were determined in terms of $\mathrm{IC}_{50}$. Zerumbone was used throughout this study as a positive control to compare the activity of ITHB4 in inhibiting the growth of MCF-7 cells. Besides, the $\mathrm{IC}_{50}$ of zerumbone was also determined. Similar protocol was repeated with MCF10A.

In vitro cytotoxicity assay of ITHB4 on PBMC culture. To test the toxicity level of $97.55 \mu \mathrm{g} / \mathrm{ml}$ of ITHB4 on human immune cells, PBMCs were seeded at $1 \times 10^{5}$ cells/well in a 96 -well plate and incubated overnight. The next day, cells were cultured with ITHB4 at the $\mathrm{IC}_{50}$ concentration for $48 \mathrm{~h}$. MTT was added to the cells in the dark for $4 \mathrm{~h}$ before the termination of the experiment by adding DMSO. The absorbance was read at a wavelength of $570 \mathrm{~nm}$ using a microplate reader. The cytotoxicity of zerumbone at the $\mathrm{IC}_{50}$ concentration was examined using similar protocols.

Detection of apoptosis. The apoptotic effect of ITHB4 and zerumbone on $\mathrm{MCF}-7$ cells at the $\mathrm{IC}_{50}$ concentrations was determined by using The Tali ${ }^{\circledR}$ Apoptosis Kit containing Annexin V Alexa Fluor ${ }^{\circledR} 488$ and propidium iodide (PI) from ThermoFisher Scientific (Waltham, MA, USA). In brief, cells were treated with the $\mathrm{IC}_{50}$ of ITHB 4 and zerumbone for $48 \mathrm{~h}$ before analysis. The cells were collected from 6-well plates using trypsin, centrifuged at $300 \times \mathrm{g}$ for $10 \mathrm{~min}$, resuspended in $\mathrm{ABB}$ (Annexin V binding buffer) and incubated with Annexin V Alexa Fluor 488 at room temperature in the dark for $20 \mathrm{~min}$. Following the centrifugation at $300 \times \mathrm{g}$ for 5 min, the cells were again resuspended in $\mathrm{ABB}$ and incubated with PI at room temperature in the dark for $5 \mathrm{~min}$. The cells were immediately examined using a Tali ${ }^{\circledR}$ Image-Based Cytometer (ThermoFisher). The data were analyzed by FCS Express Research Edition software (version 4.03; De Novo Software, New Jersey, NJ, USA) and expressed as the percentage of cells in each population such as live, dead, and apoptotic cells. A visual result was also obtained whereby apoptotic cells were stained green due to Annexin V Alexa Fluor ${ }^{\circledR} 488$, dead cells were stained with both red PI and green Annexin V Alexa Fluor ${ }^{\circledR} 488$, and live cells were not stained by either PI or Annexin V Alexa Fluor ${ }^{\circledR} 488$.

Cell cycle analysis. The effects of the ITHB4 and zerumbone on the distribution of MCF-7 cells in the cell cycle were studied using BD BrdU FITC Assay. They were treated with $97.60 \mu \mathrm{g} / \mathrm{ml}$ and 126.7 $\mu \mathrm{g} / \mathrm{ml}$ of ITHB 4 and zerumbone, respectively, for $48 \mathrm{~h}$ followed by incubation with $10 \mu \mathrm{M}$ bromodeoxyuridine (BrdU) for $30 \mathrm{~min}$. The cells were then detached with trypsin and incubated with $20 \mu \mathrm{l}$ antiBrdU-FITC for $20 \mathrm{~min}$ as well as with $2.5 \mu \mathrm{l}$ 7-amino-actinomycin 
D (7-AAD) for 15 min according to the manufacturer's instructions (BrdU Flow Kit, BD Pharmingen, San Diego, CA, USA). Analysis was performed using a BD FACSCanto II flow cytometer (BD Biosciences) and FlowJo v7.6.5 64-bit software (Treestar, Ashland, OR, USA).

Reactive oxygen species (ROS) analysis. Determination of ROS levels following incubation of MCF-7 cells with the $\mathrm{IC}_{50}$ of ITHB4 or zerumbone was performed according to the manufacturer's instructions (Mitosciences, DCFDA Cellular ROS Detection Assay Kit; Mitoscience/Abcam, Cambridge, UK). The kit uses a cell permeant reagent 2', 7'-dichlorofluorescein diacetate (DCFDA), a fluorogenic dye that measures hydroxyl, peroxyl and any other intracellular ROS. Following diffusion into the cell, DCFDA is deacetylated by cellular esterases to a non-fluorescent compound, which is subsequently oxidized by intracellular ROS into DCF. DCF is highly fluorescent and could be detected using fluorescence spectroscopy at $495 \mathrm{~nm}$ (excitation) and $529 \mathrm{~nm}$ (emission). In brief, the MCF-7 cells were seeded overnight in a 96-well plate in $100 \mu \mathrm{l}$ culture medium in the dark. On the day of experiment, the cells were incubated with $\mathrm{IC}_{50}$ of ITHB 4 and zerumbone for $48 \mathrm{~h}$. On the next day, the cells were incubated with $25 \mu \mathrm{M}$ DCFH-DA in the dark for $45 \mathrm{~min}$. Later, DCFH-DA was removed, and the cells were washed with a $1 \times$ buffer solution. The fluorescence emanating from the cells of each well was measured and recorded at $485 \mathrm{~nm}$ (excitation) and $535 \mathrm{~nm}$ (emission) using Varioskan Flash microplate reader (Thermo-Scientific).

DNA fragmentation assay. To determine the effect of ITHB4 and zerumbone on cancer cell DNA integrity, DNA fragmentation assay was conducted whereby MCF-7 cells were treated with $97.60 \mu \mathrm{g} / \mathrm{ml}$ and $126.7 \mu \mathrm{g} / \mathrm{ml}$ of ITHB 4 or zerumbone, respectively for $48 \mathrm{~h}$. Then, cells were harvested and centrifuged at $650 \times \mathrm{g}$ for $5 \mathrm{~min}$ at $4^{\circ} \mathrm{C}$. The resulting pellets were collected and the DNA was extracted using a commercial QIAamp DNA mini kit (Qiagen, Valencia, CA, USA) according to the manufacturer's instructions. The DNA quantity in each sample was measured and $10 \mu \mathrm{g}$ of the DNA were electrophoresed on $1.2 \%(\mathrm{w} / \mathrm{v})$ agarose gel. The gel was visualized using a UV light source and imaged using a Gel Doc XR gel documentation system (Bio-Rad, Hemel Hempstead, UK).

Th1/Th2/Th17 cytokines analysis. To investigate the secretion of various cytokines in the supernatant of MCF-7 cells treated with the $\mathrm{IC}_{50}$ concentration of ITHB 4 or zerumbone, a commercially available BD Cytometric Bead Array (CBA) Human Th1/Th2/Th17 Cytokine kit (BD Biosciences) was used according to the manufacturer's instructions. In brief, the supernatant of the culture was collected and filtered through a $0.22-\mu \mathrm{m}$ Steriflip ${ }^{\circledR}$ Filter (Millipore, Billerica, MA, USA). Supernatants of untreated cells were used as a negative control. The assay detects the levels of IL2, IFN- $\gamma$, TNF- $\alpha$, IL-6, IL-10, IL-4 and IL-17A. The samples were acquired on a FACSCanto II (BD Biosciences) and analyzed using the FCAP array software (BD Biosciences).

Statistical analysis. Data are presented as the mean \pm standard deviation (SD) and $n$ refers to the number of independent experiments. Levels of significance for comparisons between two or more independent samples were determined using a two-tailed unpaired Student's $t$-test. Differences were considered significant at $* p<0.05, * * p<0.01$ and $* * * p<0.001$. Groups were compared by one- way or two-way analysis of variance and Bonferroni's post hoc test was applied to explore significance using GraphPad Prism Version 8.0 (GraphPad Software Inc., La Jolla, CA, USA).

\section{Results}

Cytotoxicity level of ITHB4. MTT assay was performed to determine the cytotoxicity of the synthesized compound against the MCF-7 breast cancer cell line at two different time-points, $24 \mathrm{~h}$ and $48 \mathrm{~h}$ (Figure 3). ITHB4 significantly inhibited the growth of MCF-7 cells at all concentrations. However, the $\mathrm{IC}_{50}$ of ITHB4 was found to be lower at $48 \mathrm{~h}$ $(97.55 \mu \mathrm{g} / \mathrm{ml})$ compared to $24 \mathrm{~h}(142 \mu \mathrm{g} / \mathrm{ml})$ and it was statistically significant at a $p$-value of 0.0072 , indicating that ITHB4 inhibited MCF-7 cells more effectively at the longer time point (Figure 3A). Meanwhile, zerumbone inhibited the growth of MCF-7 cells at a lower $\mathrm{IC}_{50}$ at $48 \mathrm{~h}(126.7 \mu \mathrm{g} / \mathrm{ml})$ compared to $24 \mathrm{~h}\left(\mathrm{IC}_{50}: 127 \mu \mathrm{g} / \mathrm{ml}\right)$, however, the difference was not statistically significant with a $p$-value of 0.0649 (Figure 3B). Based on these findings, a treatment period of $48 \mathrm{~h}$ was selected for both ITHB4 and zerumbone for further analysis. A lower concentration of ITHB4 compared with zerumbone was required to reduce $\mathrm{MCF}-7$ cell growth by half (97.55 vs. $126.7 \mu \mathrm{g} / \mathrm{ml})$, and statistical significance of the difference between MCF-7 cells survival after the $48 \mathrm{~h}$ treatment with ITHB4 and zerumbone was marginal with a $p$-value of 0.048 (Figure 3C). Both ITHB4 and zerumbone did not exhibit cytotoxicity against normal breast cells and PBMCs at their respective $\mathrm{IC}_{50}$ concentration (Figure $3 \mathrm{D}, \mathrm{E}$, $F$, and G).

ITHB4 induces apoptosis in MCF-7 cells. To investigate the role of apoptosis in the antitumor effect of ITHB4, the Tali ${ }^{\circledR}$ Apoptosis Kit containing Annexin V Alexa Fluor ${ }^{\circledR} 488$ and PI was used. The results revealed that at its $\mathrm{IC}_{50}$ concentration, ITHB4 induced apoptosis of MCF-7 cells after $48 \mathrm{~h}$ of treatment; however, this effect was not greater than that of zerumbone, whereby treatment with the $\mathrm{IC}_{50}$ concentration of zerumbone resulted in an apoptosis rate of $35 \%$ compared to ITHB $4(26 \%)$ (Figure 4 A and B).

ITHB4 induced $G_{2} / M$ cell cycle arrest. BrdU FITC staining and flow cytometric analysis were performed to investigate the cell cycle phase distribution of MCF-7 cells treated with the $\mathrm{IC}_{50}$ concentration of ITHB4 for $48 \mathrm{~h}$ (Figure 5A). There was a significant increase of $39.6 \%$ in the proportion of ITHB 4 treated cells in the $\mathrm{G}_{2} / \mathrm{M}$ phase $(p<0.001)$ whereas the proportion of untreated cells was only $15.2 \%$. The proportion of cells treated with zerumbone was slightly increased by $20.5 \%$ (Figure 5B). Meanwhile, the cell population in the S phase was decreased (3.5\%) with ITHB4 and $(1.5 \%)$ zerumbone compared with untreated cells $(25 \%)$. In contrast, high proportion of zerumbone-treated cells was 


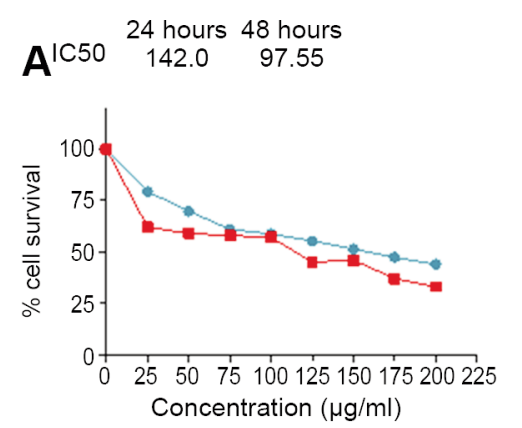

-24 hours

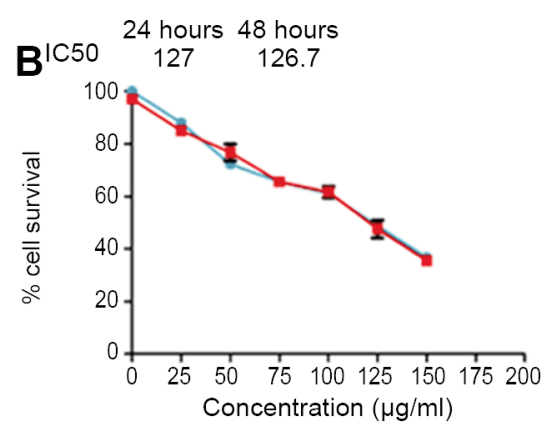

-24 hours

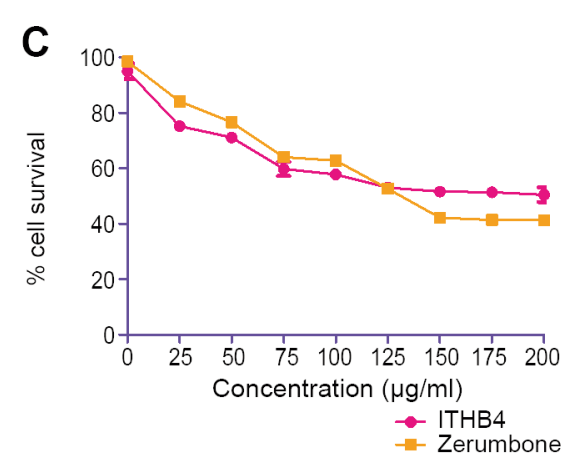

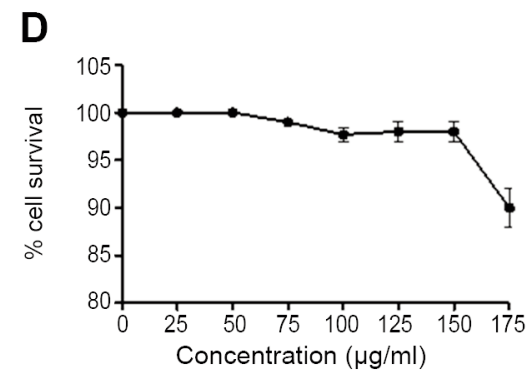

E

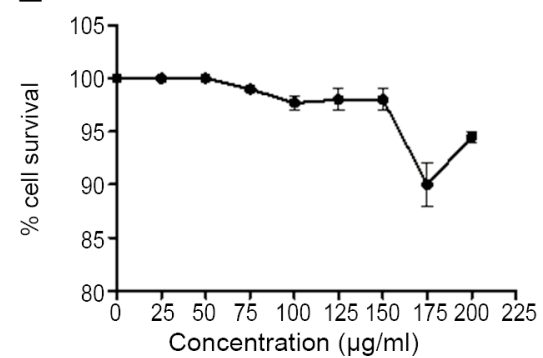

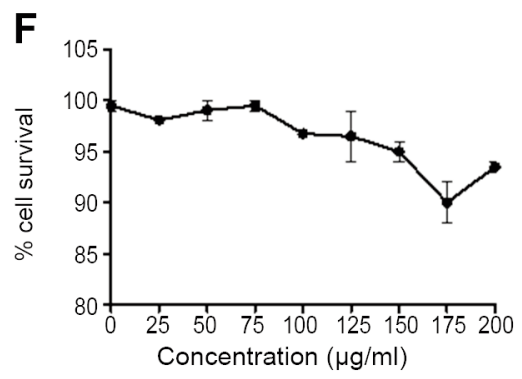

G

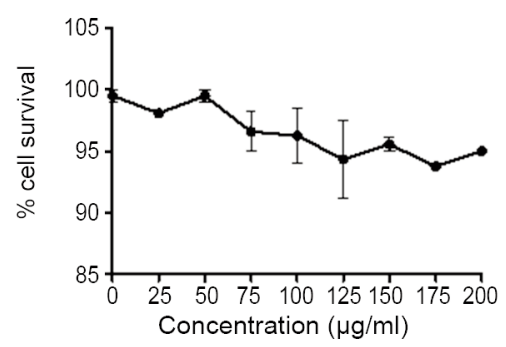

Figure 3. Comparative cytotoxicity activity of ITHB4 and zerumbone on MCF-7, MCF10A, and peripheral blood mononuclear cell (PBMC) culture at $24 \mathrm{~h}$ and $48 \mathrm{~h}$ time-points. (A) Dose-dependent inhibition of survival of MCF-7 cells treated with ITHB4 as determined by the MTT assay. Different treatment periods differentially affect the effectiveness of ITHB4 in vitro. (B) Dose-dependent inhibition of survival of MCF-7 cells treated with zerumbone as determined by the MTT assay. Different treatment periods differentially affect the effectiveness of zerumbone treatment in vitro. (C) Dose-dependent inhibition of survival of $m C F-7$ cells upon treatment of ITHB4 or zerumbone for $48 \mathrm{~h}$. (D) Dose-dependent effect of ITHB 4 treatment for $48 \mathrm{~h}$ on the survival of MCF10A cells as determined by the MTT assay. ITHB4 did not show any obvious inhibition of MCF10A cell growth. (E) Dose-dependent effect of ITHB4 treatment for $48 \mathrm{~h}$ on the survival of PBMCs as determined by the MTT assay. ITHB4 did not show any obvious inhibition in the proliferation of PBMCs. (F) Dose-dependent effect of zerumbone treatment for $48 \mathrm{~h}$ on the survival of MCF10A cells as determined by the MTT assay. Zerumbone did not show any obvious inhibition of MCF10A cells growth. (G) Dose-dependent effect of zerumbone treatment for $48 \mathrm{~h}$ on the survival of PBMCs as determined by MTT assay. Zerumbone did not show any obvious inhibition of proliferation of PBMC culture. Dose-response curves were obtained using a logistic nonlinear regression analysis model. Data are presented as mean \pm standard deviation from duplicate samples of at least two independent experiments.

found mostly at the $\mathrm{G} 0 / \mathrm{G} 1$ phase $(60.2 \%)$ compared with untreated MCF-7 cells (51\%) and ITHB4-treated cells (50\%) $(p<0.001)$. In addition, the proportion of cells in the subG0/G1 phase, which indirectly represents apoptotic cells, was also dramatically increased from $2 \%$ in the untreated cells to $6.0 \%$ and $11.3 \%$ in cells treated with $97.60 \mu \mathrm{g} / \mathrm{ml}$ and $126.7 \mu \mathrm{g} / \mathrm{ml}$ of ITHB 4 and zerumbone, respectively $(p<0.01)$. These results suggest that ITHB4 exhibited a significant antitumor effect and led to MCF-7 cell cycle arrest at the $\mathrm{G}_{2} / \mathrm{M}$ phase, whereas zerumbone appeared to arrest MCF-7 cell proliferation at the G0/G1 phase.

ITHB4 induced DNA fragmentation in MCF-7 cells. DNA degradation in a ladder-like pattern is a characteristic of cell 


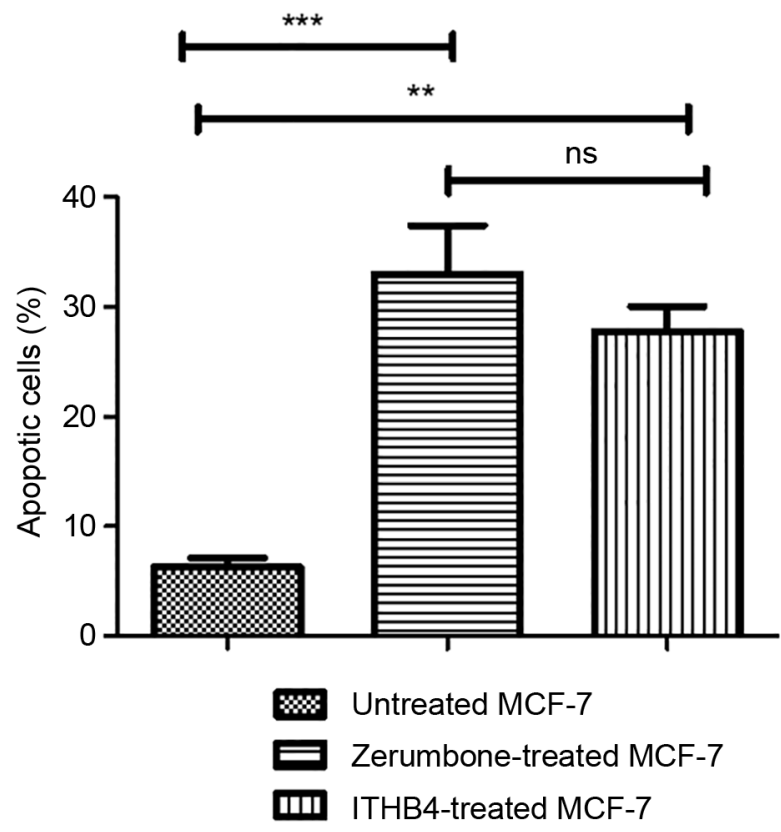

Figure 4. Percentage of apoptotic cells in untreated and treated MCF7 cells. A) ITHB4 induces apoptosis of MCF-7 cells after $48 \mathrm{~h}$ of treatment. The data represent the means \pm standard deviations (SDs) of 3 independent experiments. Statistical analysis is defined as significant if $* p<0.05, * * p<0.01$ and $* * * p<0.001 . B)$ A representative visual result from Tali $B$ Image-Based Cytometer showing apoptotic cells stained as green due to Annexin V Alexa Fluor ${ }^{\circledR} 488(a \& d)$, dead cells stained with both red PI and green Annexin V Alexa Fluor ${ }^{\circledR} 488(b)$, and live cells not stained by either PI or Annexin V Alexa Fluor ${ }^{\circledR} 488$ (c).

death caused by ROS. We observed that ITHB4 inhibited MCF-7 proliferation at the $\mathrm{G}_{2} / \mathrm{M}$ phase of the cell cycle and subsequently increased the number of cells in the sub-G1 phase, suggesting apoptosis induction. We next determined whether ITHB4 induces DNA fragmentation in MCF-7 cells. As shown in Figure 6, ITHB4 triggered the formation and appearance of apoptotic DNA fragments on agarose gel, confirming that the ITHB4 cytotoxic effect on MCF-7 cells was mediated through the apoptotic pathway. Similarly, zerumbone also induced DNA fragmentation in MCF-7 cells.

Production of cellular reactive oxygen species (ROS) in ITHB4-treated cells. Excessive cellular levels of ROS can cause damage to proteins, nucleic acids, lipids, membranes and organelles, which can lead to apoptosis. We observed a significant increase in ROS production in cells treated with ITHB4 compared to zerumbone (Figure 7), suggesting that the effects of ITHB4 might occur via the activation of mitochondria-initiated events.

Differential Th1/Th2/Th17 cytokine secretion in ITHB4 treated MCF-7 cells. To characterize the cytokine profiles released from MCF-7 cells following treatment with ITHB4 or zerumbone, we measured the expression of pro-inflammatory Th1 (IL-2, IL-6, TNF- $\alpha$ and IFN- $\gamma$ ), Th2 (IL-4), immunoregulatory (IL-10), and Th17 (IL-17A) cytokines in the culture supernatants. Figure 8 shows that both ITHB 4 and zerumbone increased the levels of IL-2, IL-6, TNF- $\alpha$, IFN- $\gamma$, IL-4, IL-10, and IL-17A compared with untreated MCF-7 cells. Specifically, IL-2, IL-6, IL-17A, and TNF- $\alpha$ showed a significant increase $(p<0.001)$. Besides, IFN- $\gamma$ and IL-10 were found to be significantly increased $(p<0.01$ and $p<0.05)$ in the culture supernatant of zerumbone-treated MCF-7 cells. In addition, higher levels of IL-4 were detected, yet the difference compared to the untreated MCF-7 cells was not significant. ITHB4 strongly enhanced the expression of TNF$\alpha$ in the treated culture supernatants $(p<0.001)$. In addition, the levels of IL-6, IL-2, and IFN- $\gamma$ were significantly increased $(p<0.01, p<0.01$ and $p<0.05$, respectively) in ITHB4-treated MCF-7 cells. However, the increase in the levels of IL-10 and IL17A cytokines in the culture supernatant of ITHB4-treated cells was not significant. These findings suggest that ITHB4 and zerumbone differentially regulate cytokine production in MCF-7 cells, and possible activate distinct pathways. Nevertheless, the elevation in the levels of TNF- $\alpha$ and IL-6 in MCF-7 cells suggest that ITHB4 and zerumbone induced inflammation and activation of the tumor cell-extrinsic pathway.

\section{Discussion}

The search for effective anti-cancer treatments remains a major challenge to researchers and oncologists. Current treatment strategies such as chemotherapy, radiation or personalized and targeted biological agents, are often only partially effective and are invariably accompanied by unwanted side effects, which can lead to tumor recurrence with more aggressive phenotypes (16). To tackle this problem, the dosage of chemotherapeutic drugs may need to be increased in clinical practice to promote better tumorkilling effects, however, this leads to an increase in the toxicity of the drugs, which is accompanied by many unwanted adverse effects, impairing body's immunity as well as increasing susceptibility to infection (17). Much research has been conducted at preclinical and clinical settings on the ability of naturally occurring compounds to treat cancer, several of which have successfully demonstrated significant reduction in disease activity with fewer side effects (18). However, the sustainability and selectivity of naturally occurring compounds are the biggest issues that need to be addressed. Hence, significant research had been performed to develop synthetic compounds derived from natural compounds that have been identified to have anti-cancer properties. These synthetic compounds have similar molecular structures to the natural compounds, 
A
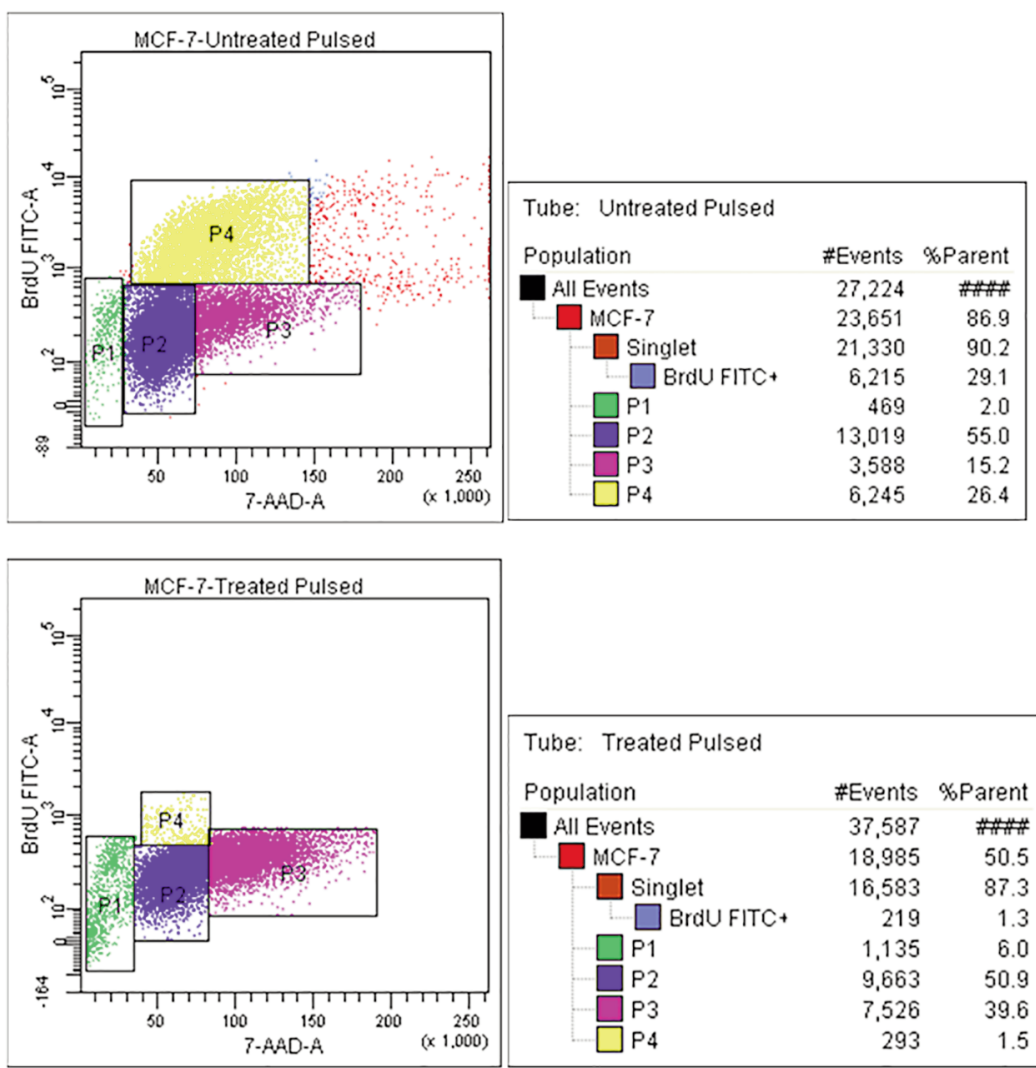

\begin{tabular}{|c|c|c|}
\hline Population & \#Events & \%Parent \\
\hline All Events & 37,587 & \#\# \\
\hline MCF-7 & 18,985 & 50.5 \\
\hline Singlet & 16,583 & 87.3 \\
\hline$\square$ BrdU FITC+ & 219 & 1.3 \\
\hline P1 & 1,135 & 6.0 \\
\hline P2 & 9,663 & 50.9 \\
\hline P3 & 7,526 & 39.6 \\
\hline$P_{4}$ & 293 & 1.5 \\
\hline
\end{tabular}

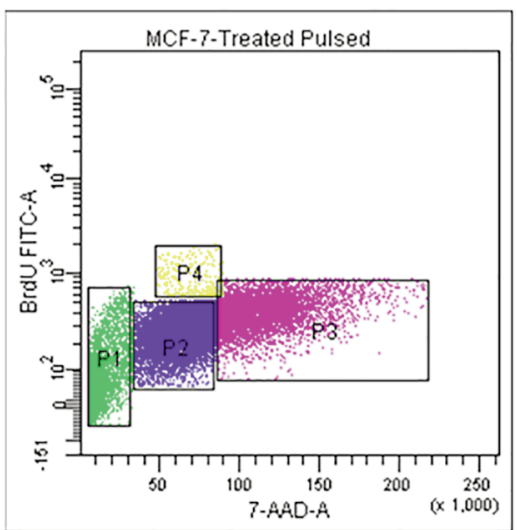

\begin{tabular}{|lrr|}
\hline Tube: Treated Pulsed & & \\
Population & \#Events & \%Parent \\
All Events & 38,742 & 58.0 \\
$\square$ MCF-7 & 22,471 & 89.2 \\
$\square$ Singlet & 20,052 & 2.2 \\
$\square$ BrdU FITC+ & 439 & 11.3 \\
$\square$ P1 & 4,359 & 35.0 \\
$\square$ P2 & 13,541 & 19.5 \\
$\square$ P3 & 7,572 & 0.9 \\
$\square$ P4 & 342 & \\
\hline
\end{tabular}

B

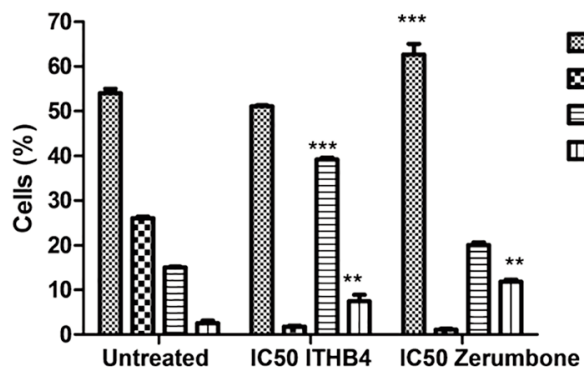

Figure 5. Cell cycle distribution of untreated and treated MCF-7 cells. A) Scatter plot of flow cytometric analysis of untreated MCF-7 cells, cells treated with the $I C_{50}$ concentration of ITHB4, and cells treated with the $I C_{50}$ concentration of zerumbone. B) Quantitative analysis indicated MCF7 cell cycle arrest at the G2/M phase following treatment with ITHB4. The data represent the means \pm SD of 3 independent experiments. Statistical analysis is defined as significant if $* p<0.05, * * p<0.01$ and $* * * p<0.001$. 


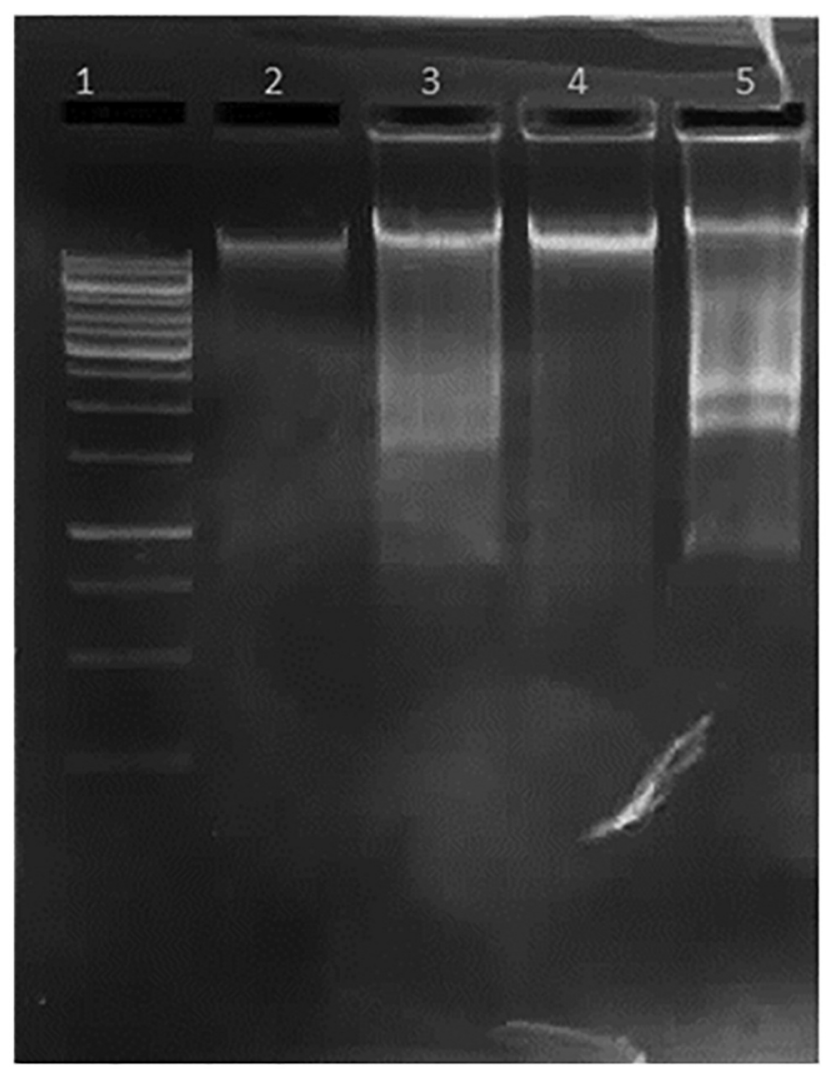

Figure 6. A 1.2\% agarose gel picture showing that ITHB4 induces DNA fragmentation. Lane 1: 1,000 bp DNA ladder, Lane 2: Untreated MCF7 cells, Lane 3: cells treated with the IC ${ }_{50}$ concentration of ITHB4, Lane 4: Untreated MCF-7 cells, and Lane 5: MCF-7 cells treated with the $I C_{50}$ concentration of zerumbone.

contain the exact active ingredients and have much safer profiles $(19,20)$.

In this study, we compared the anticancer activity of our synthetic compound ITHB4 with the natural occurring compound zerumbone on the breast carcinoma MCF-7 cells. Regarding its chemical structure, ITHB4 has benzene and pyridine rings whereby pyridine derivatives are known to possess a variety of biological activities namely antiasthmatic, anti-bacterial, anti-convulsant, anti-malarial, antimuscarinic, anti-protozoal, anti-cancer, anti-diabetic, and anti-inflammatory (21). Similarly, we found that ITHB4 demonstrated a dose-dependent induction of cell death in breast cancer cells. At the same time, zerumbone - had a similar dose-dependent cell killing effect on MCF-7 cells. However, ITHB4 displayed a lower IC $_{50}$ after treatment for 48 h compared with zerumbone. Besides, both compounds did not have any cytotoxic effects on MCF10A and PBMCs. In light of this, the findings of the present study may have significant implications regarding the incorporation of synthetic compounds into standard anticancer care.

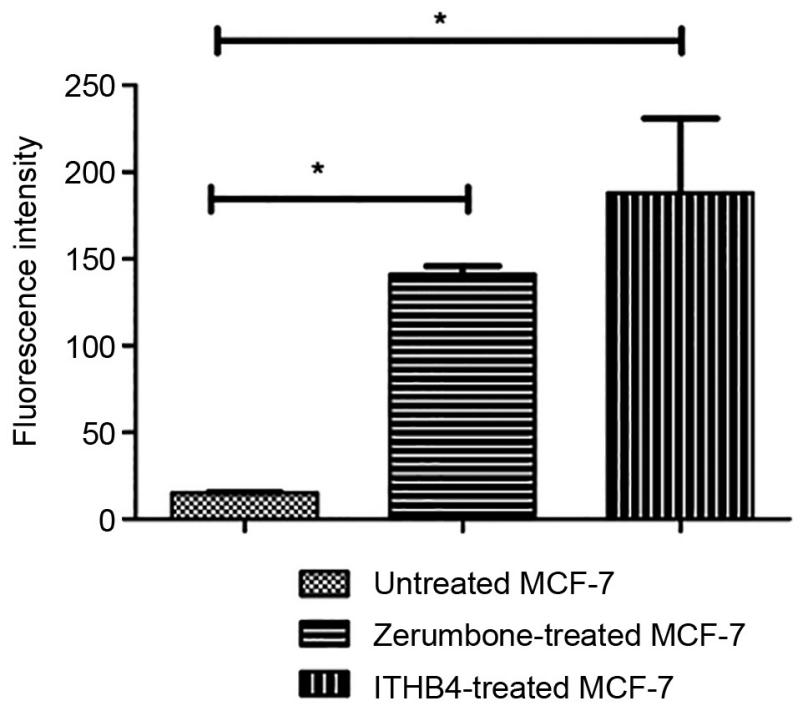

Figure 7. Reactive oxygen species (ROS) generation in treated $M C F-7$ cells. Fluorescence intensity after the treatment with the $I_{50}$ concentration of ITHB 4 or zerumbone for $48 \mathrm{~h}$. The graph shows that ITHB4 induces of the production of higher levels of cellular ROS. The data represent the means \pm standard deviations (SDs) of 3 independent experiments. Statistical analysis is defined as significant if $* p<0.05$.

Several important findings in this study indicate that ITHB 4 can be potentially used as a chemotherapeutic agent for breast cancer treatment. Firstly, ITHB4 exhibited a lower $\mathrm{IC}_{50}$ compared to zerumbone, indicating the potency of the synthetic compound. A previous study has demonstrated that synthetic compounds with a hydroxyl group on the benzene ring such as ITHB4 could have anticancer activity (22). Although ITHB4 significantly induced apoptosis of MCF-7 cells compared to untreated cells, an important mechanism responsible for the cytotoxicity of a compound (23), zerumbone was found to be more effective in killing the cancer cells, suggesting the selectivity of the natural compound against cancer cells (11). We further validated that this synthetic compound induced cell death via induction of DNA fragmentation. Our results showed that ITHB4 induced DNA fragmentation, which potentially leads to DNA damage and cell death. A similar observation was made in MCF-7 cells treated with zerumbone. DNA fragmentation is reportedly suggestive of nuclear damage during the late stages of chromatin condensation (24). This is due to cancer cells undergoing oxidative stress during treatment with ITHB4 or zerumbone, which resulted in excessive ROS production. Nevertheless, higher production of ROS was found in ITHB4- and zerumbone-treated MCF7 cells. These high cellular levels of ROS may cause damage to the proteins, nucleic acids, and organelles, which can lead to activation of cell death processes such as 

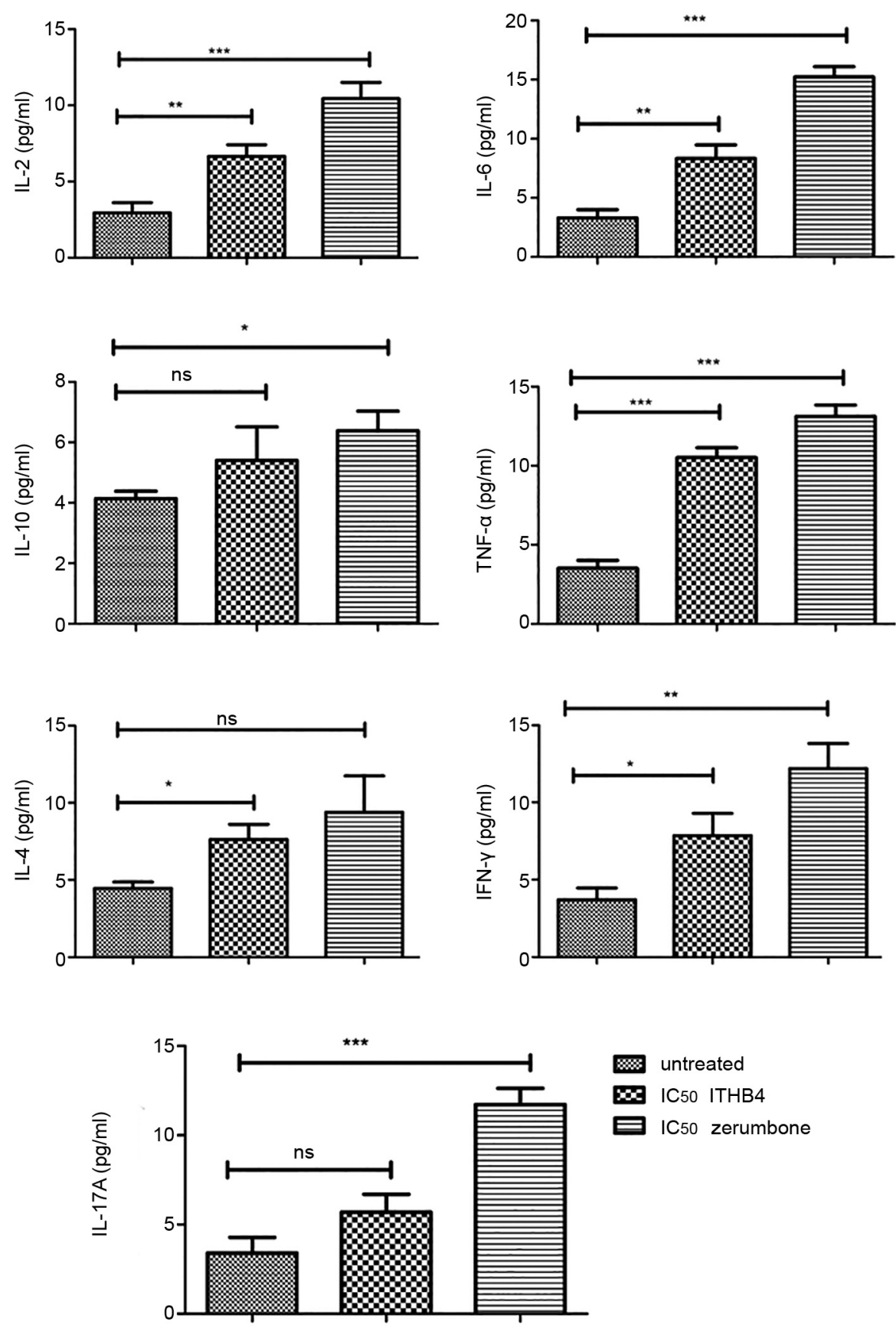

Figure 8. ITHB treatment triggers secretion of proinflammatory and anti-inflammatory cytokines in MCF-7 cells after 48 h of incubation. The data represent the means \pm standard deviations $(S D s)$ of 3 independent experiments. Statistical analysis is defined as significant if $* p<0.05, * * p<0.01$ and $* * * p<0.001 . n s:$ Non-significant.

apoptosis, and specifically mitochondrial-related apoptosis (25). This further suggests that ITHB4 uses the intrinsic mitochondrial cell death pathway to cause apoptosis in MCF-7 cells.

To further support this, an increase in the proportion of cells in the sub G0/G1 phase of the cell cycle was found in both treated MCF-7 cells and was more prominent in those treated with zerumbone. In addition, the antitumor effect of ITHB4 also led to MCF-7 cell cycle arrest at the $\mathrm{G}_{2} / \mathrm{M}$ phase, which could indicate the damage of intracellular DNA in cancer cells, leading to apoptosis (26). On the contrary, zerumbone arrested cancer cell proliferation at the $G_{0} / G_{1}$ 
phase of the cell cycle, indicating that zerumbone may have a role in inhibiting cancer cell division (10). Our findings also indicated that treatment of MCF-7 cells with ITHB4 or zerumbone affected similarly the secretion of cytokines. Nevertheless, secretion of these cytokines was upregulated in zerumbone-treated cancer cells. ITHB4 upregulated various proinflammatory cytokines, especially TNF- $\alpha$ and IL-6. This suggests that excessive inflammation was induced in the treated cells that could potentially lead to immunogenic cell death by sending signals to immune cells, such as dendritic cells, to act on treated cells $(27,28)$. Activation of IL-6 indicates activation of receptor mediated cell death and at the same time, secretion of ROS may also potentially induce activation of the mitochondrial cell death pathway. The increase in the levels of secreted IL-10 from cells treated with ITHB4, although not statistically significant, enhances the expression of proinflammatory cytokines or activation of immune response. In support, it has been shown that too much IL-10 could lead to the inhibition of $\mathrm{T}$ cell proliferation and tumor growth (29).

We acknowledge that this study has several limitations. First, the investigation of the apoptosis pathway associated with ITHB4-induced cell cycle arrest in MCF-7 cells can be further explored via several other techniques including cycle-related, apoptosis-related, and DNA damage-related gene expression analysis. This would further validate our findings in this study pertaining the apoptotic effects induced by ITHB4 compared to zerumbone (30). Second, several other types of breast cancer cell lines such as MDA-MB-231, MDA-MB-453 and others, along with cell lines derived from different tumor types, should also be used in future studies to validate that the antitumor effect of ITHB4 is not cancer cell-specific (31).

\section{Conclusion}

In this work, we report the cytotoxic activity of ITHB4, which has been assessed against the MCF-7 cell line. In comparison to zerumbone, ITHB4 displayed a lower $\mathrm{IC}_{50}$ in the cell proliferation assay, suggesting the potency of the compound, and the ability to induce apoptosis through the release of ROS, DNA fragmentation and cell cycle arrest at the $G_{2} / M$ phase. Taken together, this study provides evidence that compounds based on the isoniazid drug, which have been used to treat tuberculosis, could be further explored for the discovery of new leading compounds against breast cancer.

\section{Conflicts of Interest}

The Authors wish to confirm that there are no known conflicts of interest associated with this publication and there has been no significant financial support for this work that could have influenced its outcome.

\section{Authors' Contributions}

KMV, VM and NKHS designed the project. MB performed the experiments, analyzed the data and wrote the manuscript. AKZ was involved in manuscript drafting and editing. JV was involved in obtaining the funding, experimental design and manuscript drafting. All Authors discussed the results and contributed to the manuscript.

\section{Acknowledgements}

This work was supported by Fundamental Research Grant Scheme (FRGS) (FP109-2019A), a grant from Ministry of Education (MOE) for a study entitled 'anticancer activity of hyperforin against breast cancer cells: identification of cell death and autophagy pathways'. Muttiah BARATHAN was supported by the University Malaya Student Financial Aid by IPPP, UM. However, the funders had no role in this study.

\section{References}

1 Sung H, Ferlay J, Siegel RL, Laversanne M, Soerjomataram I, Jemal A and Bray F: Global Cancer Statistics 2020: GLOBOCAN estimates of incidence and mortality worldwide for 36 cancers in 185 countries. CA Cancer J Clin 71(3): 209249, 2021. PMID: 33538338. DOI: 10.3322/caac.21660

2 Cardoso F, Kyriakides S, Ohno S, Penault-Llorca F, Poortmans P, Rubio IT, Zackrisson S, Senkus E and ESMO Guidelines Committee. Electronic address: clinicalguidelines@esmo.org: Early breast cancer: ESMO Clinical Practice Guidelines for diagnosis, treatment and follow-up $\dagger$. Ann Oncol 30(8): 11941220, 2019. PMID: 31161190. DOI: 10.1093/annonc/mdz173

3 Pucci C, Martinelli C and Ciofani G: Innovative approaches for cancer treatment: current perspectives and new challenges. Ecancermedicalscience 13: 961, 2019. PMID: 31537986. DOI: 10.3332/ecancer.2019.961

4 Marhold M, Tomasich E, Schwarz M, Udovica S, Heinzel A, Mayer P, Horak P, Perco P and Krainer M: Synthetic lethal combinations of low-toxicity drugs for breast cancer identified in silico by genetic screens in yeast. Oncotarget 9(91): 3637936391, 2018. PMID: 30555636. DOI: 10.18632/oncotarget. 26372

5 Khalifa SAM, Elias N, Farag MA, Chen L, Saeed A, Hegazy MF, Moustafa MS, Abd El-Wahed A, Al-Mousawi SM, Musharraf SG, Chang FR, Iwasaki A, Suenaga K, Alajlani M, Göransson U and El-Seedi HR: Marine natural products: A source of novel anticancer drugs. Mar Drugs 17(9): 491, 2019. PMID: 31443597. DOI: 10.3390/md17090491

6 Falzone L, Salomone S and Libra M: Evolution of cancer pharmacological treatments at the turn of the third millennium. Front Pharmacol 9: 1300, 2018. PMID: 30483135. DOI: 10.3389/ fphar.2018.01300

7 Lamb R, Ozsvari B, Lisanti CL, Tanowitz HB, Howell A, Martinez-Outschoorn UE, Sotgia F and Lisanti MP: Antibiotics that target mitochondria effectively eradicate cancer stem cells, across multiple tumor types: treating cancer like an infectious disease. Oncotarget 6(7): 4569-4584, 2015. PMID: 25625193. DOI: $10.18632 /$ oncotarget.3174

8 Gao Y, Shang Q, Li W, Guo W, Stojadinovic A, Mannion C, Man YG and Chen T: Antibiotics for cancer treatment: A double- 
edged sword. J Cancer 11(17): 5135-5149, 2020. PMID: 32742461. DOI: $10.7150 /$ jca.47470

9 Parumasivam T, Naveen kumar H, Ibrahim P, Sadikun A and Mohamad S: Anti-tuberculosis activity of lipophilic isoniazid derivatives and their interactions with first-line anti-tuberculosis drugs. Journal of Pharmacy Research 7(4): 313-317, 2018. DOI: 10.1016/j.jopr.2013.04.039

10 Naveen kumar H, Parumasivam T, Jumaat F, Ibrahim P, Asmawi M and Sadikun A: Synthesis and evaluation of isonicotinoyl hydrazone derivatives as antimycobacterial and anticancer agents. Medicinal Chemistry Research 23(1): 269-279, 2020. DOI: 10.1007/s00044-013-0632-2

11 Girisa S, Shabnam B, Monisha J, Fan L, Halim CE, Arfuso F, Ahn KS, Sethi G and Kunnumakkara AB: Potential of zerumbone as an anti-cancer agent. Molecules 24(4): 734, 2019. PMID: 30781671. DOI: 10.3390/molecules24040734

12 Lallo S, Kasim S, Tayeb R, Hasan A, Sere H, Ismail I and Arifin T: Analisis Zerumbone Dalam Zingiber zerumbet Dan Aktivitas Penghambatannya Terhadap Bakteri Mycobacterium tuberculosis. Jurnal Farmasi Galenika (Galenika Journal of Pharmacy) (e-Journal) 4(2): 126-132, 2020. DOI: 10.22487/ j24428744.2018.v4.i2.11138

13 E M Eid E, S Alanazi A, Koosha S, A Alrasheedy A, Azam F, M Taban I, Khalilullah H, Sadiq Al-Qubaisi M and A Alshawsh M: Zerumbone induces apoptosis in breast cancer cells by targeting $\alpha v \beta 3$ integrin upon co-administration with TP5-iRGD peptide. Molecules 24(14): 2554, 2019. PMID: 31337024. DOI: 10.3390/ molecules 24142554

14 Naveenkumar HS, Sadikun A, Ibrahim P, Goh JH and Fun HK: (E)-N'-(2,3,4-Trihy-droxy-benzyl-idene)-isonicotinohydrazide dihydrate. Acta Crystallogr Sect E Struct Rep Online 66(Pt 11): o3017-03018, 2010. PMID: 21589176. DOI: 10.1107/ S1600536810043965

15 Barathan M, Mohamed R, Vadivelu J, Chang LY, Vignesh R, Krishnan J, Sigamani P, Saeidi A, Ram MR, Velu V, Larsson M and Shankar EM: CD8+ T cells of chronic HCV-infected patients express multiple negative immune checkpoints following stimulation with HCV peptides. Cell Immunol 313: 19, 2017. PMID: 28104239. DOI: 10.1016/j.cellimm.2016.12.002

16 Arruebo M, Vilaboa N, Sáez-Gutierrez B, Lambea J, Tres A, Valladares $\mathrm{M}$ and González-Fernández A: Assessment of the evolution of cancer treatment therapies. Cancers (Basel) 3(3): 3279-3330, 2011. PMID: 24212956. DOI: 10.3390/ cancers 3033279

17 Maeda $\mathrm{H}$ and Khatami M: Analyses of repeated failures in cancer therapy for solid tumors: poor tumor-selective drug delivery, low therapeutic efficacy and unsustainable costs. Clin Transl Med 7(1): 11, 2018. PMID: 29541939. DOI: 10.1186/ s40169-018-0185-6

18 Hosseini A and Ghorbani A: Cancer therapy with phytochemicals: evidence from clinical studies. Avicenna J Phytomed 5(2): 84-97, 2015. PMID: 25949949.

19 Atanasov AG, Waltenberger B, Pferschy-Wenzig EM, Linder T, Wawrosch C, Uhrin P, Temml V, Wang L, Schwaiger S, Heiss EH, Rollinger JM, Schuster D, Breuss JM, Bochkov V, Mihovilovic MD, Kopp B, Bauer R, Dirsch VM and Stuppner $\mathrm{H}$ : Discovery and resupply of pharmacologically active plantderived natural products: A review. Biotechnol Adv 33(8): 15821614, 2015. PMID: 26281720. DOI: 10.1016/j.biotechadv. 2015.08 .001
20 Pinto DCGA and Silva AMS: Anticancer natural coumarins as lead compounds for the discovery of new drugs. Curr Top Med Chem 17(29): 3190-3198, 2017. PMID: 29243581. DOI: $10.2174 / 1568026618666171215095750$

21 Shang XF, Morris-Natschke SL, Liu YQ, Guo X, Xu XS, Goto M, Li JC, Yang GZ and Lee KH: Biologically active quinoline and quinazoline alkaloids part I. Med Res Rev 38(3): 775-828, 2018. PMID: 28902434. DOI: 10.1002/med.21466

22 Liew SK, Malagobadan S, Arshad NM and Nagoor NH: A review of the structure-activity relationship of natural and synthetic antimetastatic compounds. Biomolecules 10(1): 138, 2020. PMID: 31947704. DOI: 10.3390/biom 10010138

23 Jamalzadeh L, Ghafoori H, Aghamaali M and Sariri R: Induction of apoptosis in human breast cancer MCF-7 cells by a semisynthetic derivative of artemisinin: A caspase-related mechanism. Iran J Biotechnol 15(3): 157-165, 2017. PMID: 29845064. DOI: $10.15171 /$ ijb.1567

24 Fakai MI, Abd Malek SN and Karsani SA: Induction of apoptosis by chalepin through phosphatidylserine externalisations and DNA fragmentation in breast cancer cells (MCF7). Life Sci 220: 186-193, 2019. PMID: 30682342. DOI: 10.1016/j.lfs.2019.01.029

$25 \mathrm{Kim}$ SJ, Kim HS and Seo YR: Understanding of ROS-inducing strategy in anticancer therapy. Oxid Med Cell Longev 2019: 5381692, 2019. PMID: 31929855. DOI: $10.1155 / 2019 / 5381692$

26 Pan Z, Zhang X, Yu P, Chen X, Lu P, Li M, Liu X, Li Z, Wei F, Wang K, Zheng Q and Li D: Cinobufagin induces cell cycle arrest at the G2/M phase and promotes apoptosis in malignant melanoma cells. Front Oncol 9: 853, 2019. PMID: 31552178. DOI: $10.3389 /$ fonc. 2019.00853

27 Barathan M, Mariappan V, Shankar EM, Abdullah BJ, Goh KL and Vadivelu J: Hypericin-photodynamic therapy leads to interleukin-6 secretion by HepG2 cells and their apoptosis via recruitment of $\mathrm{BH} 3$ interacting-domain death agonist and caspases. Cell Death Dis 4: e697, 2013. PMID: 23807226. DOI: 10.1038/cddis.2013.219

28 Wang $\mathrm{X}$ and Lin Y: Tumor necrosis factor and cancer, buddies or foes? Acta Pharmacol Sin 29(11): 1275-1288, 2008. PMID: 18954521. DOI: $10.1111 / \mathrm{j} .1745-7254.2008 .00889 . x$

29 Dennis KL, Blatner NR, Gounari F and Khazaie K: Current status of interleukin-10 and regulatory T-cells in cancer. Curr Opin Oncol 25(6): 637-645, 2013. PMID: 24076584. DOI: 10.1097/CCO.0000000000000006

30 Sun Y, Zhang W, Chen Y, Ma Q, Wei J and Liu Q: Identifying anti-cancer drug response related genes using an integrative analysis of transcriptomic and genomic variations with cell linebased drug perturbations. Oncotarget 7(8): 9404-9419, 2016. PMID: 26824188. DOI: 10.18632/oncotarget.7012

31 Wang X, Yang Y, An Y and Fang G: The mechanism of anticancer action and potential clinical use of kaempferol in the treatment of breast cancer. Biomed Pharmacother 117: 109086, 2019. PMID: 31200254. DOI: 10.1016/j.biopha.2019.109086 